\title{
THE STATE OF FORCED MIGRATION AND THE MAIN PROBLEMS OF INTERNALLY DISPLACED PERSONS IN UKRAINE
}

Formulation of the problem. The military-political conflict, which began in 2014 on the territory of eastern Ukraine, has led to a number of devastating consequences, among which one of the leading places is occupied by a significant amount of forced migration. This process has led to a number of additional problems related to maintaining the quality of life of displaced persons in general, the need for social protection, housing and employment, and the social adaptation of displaced persons in the new territorial communities.

The Ukrainian economy as a result of the military conflict in Donbass is under threat of strengthening of macroeconomic imbalances and functions in unprecedented conditions of physical destruction production capacity. The largest reductions were registered in the production of coke and refined petroleum products, mechanical engineering, metallurgical production and the chemical industry. The situation is complicated by the fact that a quarter of the existing domestic export potential is directly or indirectly concentrated in the conflict zone, as a result of which the threats of its irreversible loss are growing. The military destabilization of Donbass has a negative effect on the domestic market of other regions, where the formation of a deficit on certain commodity items is recorded. Most of the migrants from the territory of the so-called DPR and LPR, primarily from the zone of armed conflict, migrated to the government-controlled territory of Ukraine. In this way, they have acquired the status of internally displaced persons (IDPs), who need to create effective mechanisms that can minimize the barrier between IDPs and communities, the needs of IDPs and the ability of the state and local authorities to meet them.

At the same time, a prerequisite for the development and targeted application of such mechanisms is the availability of analytics on the state and features of the geographical distribution of IDP migration flows.

Analysis of recent research and publications. Theoretical and practical aspects of the social protection system in Ukraine are considered by many domestic scientists and researchers who have accumulated a significant amount of theoretical material and practical achievements.
In particular, O. Romanyuk's research is focused on the state of financing social protection. O. Vasylyk and I. Kichko in their works consider social insurance as an element of the financial mechanism of social protection. However, the problems of internally displaced persons and ways to adapt them to new social conditions have a substantive relevance of research and a low level of research.

The purpose of the article is to identify the features of forced migration of internally displaced persons in Ukraine.

Presentation of the main research material. Current events in eastern Ukraine have once again confirmed that the essence of the war and the content of the armed struggle can change radically. They clearly show examples of the so-called "war without rules", when the primary targets of attack are not personnel, equipment or weapons of the armed forces of the state, but the infrastructure, human resources that ensure its smooth operation. High concentration of nuclear and chemical industry facilities, hydraulic structures, as well as life support and communications facilities, in case of targeted influence of sabotage groups and illegal formations, can lead to critical circumstances, paralyze life and provoke the movement of thousands of people. When developing state economic policy, it is necessary to take into account the peculiarities of modern hybrid warfare: the widespread use of terrorist methods of struggle; lack of a single front line; significant concentration of forces and means while covering large areas; the ability of the enemy to selectively inflict point blows on important centers, when it is thought that there is no visible enemy, but his presence is felt everywhere. Under these conditions, it is necessary to unite the forces and means of the relevant ministries and other central executive bodies of Ukraine into a single system; to develop a set of national and special security measures and create an appropriate group of troops that will be able to effectively resist the forces of the modern enemy.

In 2019, five years have passed since the abbreviation IDP entered the social and scientific discourse of modern Ukraine, and the phenomenon itself appeared internally displaced persons. 
In order to legislate the status, the Law of Ukraine "On Ensuring the Rights and Freedoms of Internally Displaced Persons" was adopted, which entered into force on November 22, 2014. The law stipulates that an internally displaced person is a citizen of Ukraine, a foreigner or a stateless person Ukraine is lawful and has the right to permanent residence in Ukraine, which has been forced to leave or leave its place of residence as a result of or in order to avoid the negative consequences of armed conflict, temporary occupation, widespread violence, human rights violations and natural or manmade emergencies.

Since 2014, when many citizens were forced to leave eastern Ukraine and Crimea, Ukraine has ranked fourth on the overall list of countries with the largest number of internally displaced persons. According to international organizations, in 2015, due to the conflict in Donbass, 942 thousand people received the status of internally displaced persons [1]. However, these indicators did not reflect the real picture, as the registration process was rather slow. Thus, according to the Ministry of Social Policy, as of May 4, 2016, 1,783,361 internally displaced persons from Donbass and Crimea were already registered in Ukraine.

Note that public institutions in accordance with certain rules operate only documented data on the number of migrants and naturally do not take into account those migrants who for various reasons did not register with the established state authorities in new places of residence or did not seek help. In the following years, there were small fluctuations in the number of migrants, due to both natural decline and socio-economic factors. In particular, $95 \%$ of IDPs currently living in the Kyiv region rent housing.

The lion's share of migrants are people from the industrial cities of the region, with appropriate professional training, work experience and life guidelines. Therefore, a significant part of them, even with housing, are unlikely to agree to settle in rural areas or small towns and cities, where, incidentally, it is usually more difficult to find any work, not to mention the purely urban nature of the occupations of the vast majority of migrants.

In such conditions, the limited opportunity to find a high-paying job that will allow them to rent housing in large cities forces some migrants to return home despite their previous decision to live in a free Ukraine. As a result of these factors, according to the portal "Word and Deed", in Ukraine there is a negative trend in the number of registered migrants. Thus, the number of internally displaced persons in Ukraine in March 2018 amounted to $1,492,500$ people.

Regarding the distribution of migrants in the country as a whole, the geography has remained unchanged. Most IDPs lived in the Donetsk region -543 131 people, Luhansk region - 290.5 thousand people and in Kyiv 161558 people. As before, a minority of migrants choose the western region of the country: in the Chernivtsi region only 2498 IDPs live, and in Lviv - 12.3 thousand [2]. At the same time, observers note fluctuations in the number of internally displaced persons in the regions, which mostly reflect all-Ukrainian migration trends.

In particular, the gradual increase in the number of migrants in the Kyiv region fully correlates with the general movement of the population within the country. It should be noted that the negative dynamics of the number of migrants persists. Thus, as of October 21, 2019, according to the Unified Information Database on Internally Displaced Persons, 1,413,649 migrants from the temporarily occupied territories of Donetsk and Luhansk regions were registered, and the Autonomous Republic of Crimea [3]. At the same time, experts draw attention to the fact that official statistics do not reflect the real state of affairs. First, to date, not all IDPs have registered or regularly confirm their status with the relevant social security authorities.

Secondly, certain problems in the calculation of the actual number of IDPs are created due to the peculiarities of the calculation of social benefits and, first of all, pensions for the inhabitants of the occupied territories.

The armed conflict in eastern Ukraine and the annexation of the Autonomous Republic of Crimea led to the fact that as of May 6, 2019, 1,377,468 IDPs from the temporarily occupied territories of Donetsk and Luhansk regions and the Autonomous Republic of Crimea were registered according to the Unified Information Database on Internally Displaced Persons [4]. A detailed review of the statistics of the state of migrants is provided by the Ministry of Social Policy of Ukraine (Fig. 1).

As can be seen from the above data, the number of such persons has a declining trend, due to a number of reasons, the main of which is the transition of individuals from IDP status to local population due to lack of desire to renew the necessary documents (including IDP assistance) in a new place of residence, return to their homes due to the cessation of the active phase of hostilities.

Note that data on the number of IDPs under the existing methodology for their determination cannot be a priori reliable. First of all, many IDPs did not receive this status officially at all. It should also be noted that many IDPs, who at one time or another received the appropriate status, are not actually IDPs, but make "shuttle" trips from the area not controlled by the Ukrainian government to the controlled territory due to the desire to receive pensions, social assistance or for other legal or economic reasons. Along with the problems of social benefits and pensions, an important factor in fluctuations in the number of migrants and their quality of life in a free Ukraine is insufficient access to quality housing, which experts believe has a direct impact on relocation trends and cases of return to temporarily occupied territories or zones combat operations. The state has taken some steps to address this issue.

In particular, the order of the Cabinet of Ministers of Ukraine of November 15, 2017 № 909-r approved 
I. Smyrnova, V. Chebotarova, Yu. Kotelevets, D. Kurbatska

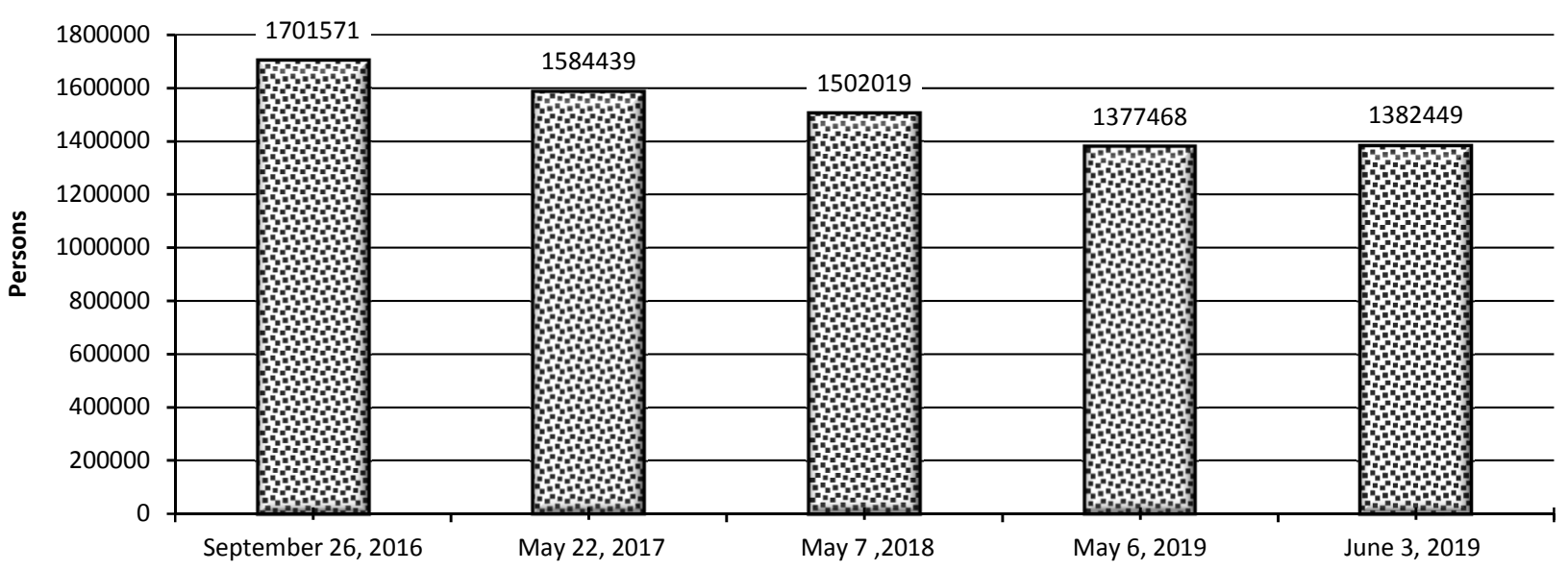

Fig. 1. Dynamics of the number of IDPs in Ukraine for 2016-2019

(formed by the authors based on source [4])

the strategy of integration of internally displaced persons and implementation of long-term decisions on internal displacement for the period up to 2020. In accordance with Part 1 of Art. 9 of the Law of Ukraine "On Ensuring the Rights and Freedoms of Internally Displaced Persons", IDPs have the right to provide state executive bodies, local governments and private law entities with the possibility of free temporary residence (subject to payment of utility costs) for six months from the date of registration of IDPs [5].

However, there is no procedure for obtaining such housing. The law stipulates that such housing for IDPs must be provided by state executive bodies, local selfgovernment bodies and private law entities. Local council leaders are considering providing IDPs with free housing, if such housing is on the balance of local councils, and finding housing in rural areas that has not been used for a long time and can be rented out or sold at an affordable price.

Citizens in need of better living conditions, in particular IDPs - war invalids, defined in paragraphs 1114 of Part 2 of Art. 7 of the Law of Ukraine "On the status of war veterans, guarantees of their social protection" [6], and members of their families have the right to receive the use of housing in public or public housing in the manner prescribed by the legislation of Ukraine. Among the normative and legal documents that have been adopted recently is the Resolution of the Cabinet of Ministers "On the provision of housing for internally displaced persons who defended the independence, sovereignty and territorial integrity of Ukraine" of April 18, 2018.

The resolution approves the procedure and conditions for providing a subvention from the state budget to local budgets for the payment of monetary compensation for housing available to IDPs, which protected the independence, sovereignty and territorial integrity of Ukraine; the procedure for payment of monetary compensation for housing available to IDPs, which protected the independence, sovereignty and territorial integrity of Ukraine [7].
The procedure for payment of monetary compensation for eligible housing for IDPs, which protected the independence, sovereignty and territorial integrity of Ukraine, was approved in the resolution of the Cabinet of Ministers of Ukraine of April 18, 2018 [7].

This document defined the mechanism of providing a subvention from the state budget to local budgets for the payment of monetary compensation for housing available to IDPs, which protected the independence, sovereignty and territorial integrity of Ukraine. The subvention is aimed at paying monetary compensation for eligible housing in commissioned residential buildings in the primary and secondary real estate markets or at investing in housing construction.

In modern conditions, we have a number of changes to this resolution: it is allowed to move from district to district and within the region during the year, if it does not lead to an increase in compensation; compensation is also calculated for disabled parents and fulltime children up to 23 years of age; settled issues of documenting the purchase of housing on the land; taken into account the issues of an exhaustive list of documents required to obtain compensation and registration of housing; Participants in a Joint Forces Operation (JFO) will also be entitled to compensation; those who had housing in the controlled area, but it was destroyed, will also be entitled to compensation.

The analysis of the content of modern documents allowed to identify a number of problems in the existing legal mechanism: 1) the absence in the documents of the procedure for appealing and conducting proceedings against the decision of the regional departments of the State Youth Housing and Commission; 2) lack of a list of required documents from developers; 3) Resolution of the Cabinet of Ministers of Ukraine № 819 does not exclude the possibility of reconstruction as an alternative to new buildings [8]; 4) the lack of clear rules and regulations governing the queue for housing; 5) improper procedure for informing about the queue on the relevant sites of the regional administration; 6) no de- 
pendence of the amount of funding for the state program on the number of IDPs living in the region.

In fact, the specific, hybrid nature of the militarypolitical conflict has determined the main feature of IDP migration flows in Ukraine: migrants are almost not concentrated in compact settlements, at least over time this trend becomes more pronounced, as most solve housing issues by personal efforts. Thus, in May 2016,
6,518 people lived in compact places of residence (hereinafter referred to as IDPs), which is approximately $0.38 \%$ of the total number of registered IDPs in Ukraine, as of January 1, 2019, this figure is 7,726 people (Fig. 2).

Structural characteristics of geographical flows of IDPs migration in Ukraine in terms of working capacity are presented in Table.

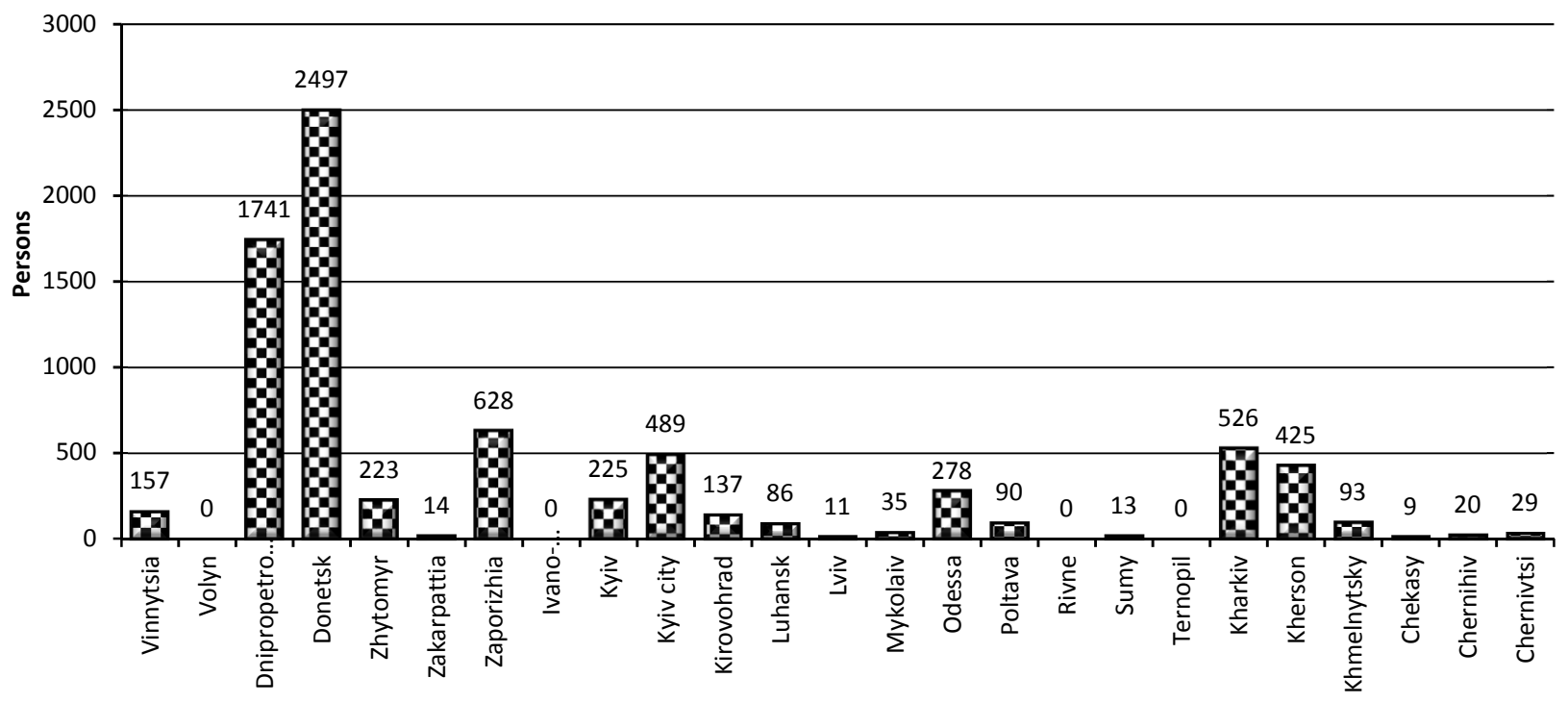

Fig. 2. Number of IDPs placed in the INC in 2016-2018

(formed by the authors based on source [9])

The structure of the peculiarities of the geography of IDPs migration in terms of working capacity

(formed by the authors based on source [9])

\begin{tabular}{|c|c|c|c|c|c|c|c|c|}
\hline \multirow[t]{2}{*}{ Region } & \multicolumn{2}{|c|}{ People of working age } & \multicolumn{2}{|c|}{ Children } & \multicolumn{2}{|c|}{ The disabled } & \multicolumn{2}{|c|}{ People of retirement age } \\
\hline & 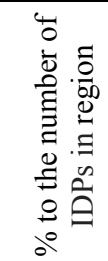 & 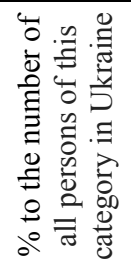 & 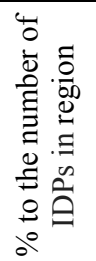 & 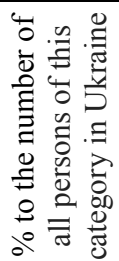 & 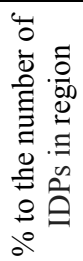 & 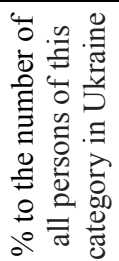 & 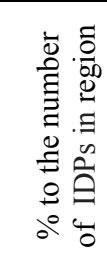 & 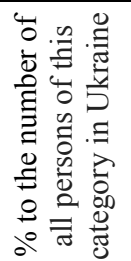 \\
\hline 1 & 2 & 3 & 4 & 5 & 6 & 7 & 8 & 9 \\
\hline Vinnytsia region & 34.0 & 1.1 & 16.3 & 0.8 & 5.1 & 1.0 & 23.4 & 0.3 \\
\hline Volyn region & 42.8 & 0.4 & 20.9 & 0.3 & 4.3 & 0.3 & 20.5 & 0.1 \\
\hline Dnipropetrovsk region & 32.9 & 7.2 & 17.7 & 6.1 & 4.4 & 6.1 & 39.6 & 3.9 \\
\hline Donetsk region & 13.5 & 21.3 & 13.8 & 34.5 & 3.5 & 35.2 & 62.3 & 43.8 \\
\hline Zhytomyr region & 33.5 & 0.7 & 22.9 & 0.8 & 5.7 & 0.8 & 29.3 & 0.3 \\
\hline Zakarpattia region & 41.0 & 0.4 & 26.5 & 0.4 & 3.8 & 0.3 & 17.9 & 0.1 \\
\hline Zaporizhia region & 26.9 & 4.6 & 14.3 & 3.9 & 4.5 & 4.9 & 53.7 & 4.1 \\
\hline Ivano-Frankivsk region & 44.5 & 0.5 & 19.1 & 0.3 & 4.8 & 0.3 & 20.5 & 0.1 \\
\hline Kyiv region & 33.2 & 5.8 & 19.1 & 5.3 & 3.6 & 4.0 & 25.5 & 0.2 \\
\hline Kirovohrad region & 28.2 & 0.6 & 22.5 & 0.8 & 5.4 & 0.7 & 35.3 & 0.3 \\
\hline Luhansk region & 11.0 & 9.6 & 7.9 & 10.9 & 2.9 & 16.2 & 72.4 & 28.1 \\
\hline Lviv region & 34.8 & 1.2 & 26.1 & 1.4 & 3.1 & 0.7 & 13.5 & 0.1 \\
\hline Mykolaiv region & 40.7 & 1.1 & 24.6 & 1.0 & 4.9 & 0.8 & 26.2 & 0.3 \\
\hline Odessa region & 38.1 & 4.3 & 22.6 & 4.0 & 4.1 & 2.9 & 21.4 & 1.1 \\
\hline Poltava region & 28.5 & 2.1 & 18.8 & 2.2 & 5.6 & 2.6 & 35.9 & 1.2 \\
\hline Rivne region & 33.8 & 0.3 & 31.1 & 0.5 & 4.1 & 0.3 & 16.9 & 0.1 \\
\hline Sumy region & 27.4 & 1.0 & 21.0 & 1.2 & 6.0 & 1.4 & 35.3 & 0.6 \\
\hline Ternopil region & 37.4 & 0.3 & 24.4 & 0.3 & 6.0 & 0.3 & 24.2 & 0.1 \\
\hline Kharkiv region & 33.0 & 13.3 & 12.5 & 8.0 & 3.2 & 8.4 & 40.5 & 7.3 \\
\hline
\end{tabular}


I. Smyrnova, V. Chebotarova, Yu. Kotelevets, D. Kurbatska

\begin{tabular}{|c|c|c|c|c|c|c|c|c|}
\hline & & & & & & & \multicolumn{2}{|c|}{ Ending of Table } \\
\hline 1 & 2 & 3 & 4 & 5 & 6 & 7 & 8 & 9 \\
\hline Kherson region & 40.0 & 1.6 & 15.0 & 1.0 & 4.1 & 1.1 & 30.4 & 0.6 \\
\hline Khmelnytsky region & 26.7 & 0.5 & 18.6 & 0.5 & 5.1 & 0.6 & 28.2 & 0.2 \\
\hline Chekasy region & 33.0 & 1.2 & 24.2 & 1.4 & 5.6 & 1.3 & 32.1 & 0.5 \\
\hline Chernivtsi region & 43.0 & 0.3 & 30.3 & 0.4 & 4.3 & 0.2 & 16.8 & 0.1 \\
\hline Chernihiv region & 28.1 & 0.6 & 21.9 & 0.8 & 4.9 & 0.7 & 29.6 & 0.3 \\
\hline Kyiv city & 45.9 & 20.0 & 19.1 & 13.2 & 3.2 & 8.9 & 22.9 & 4.5 \\
\hline Total & 22.8 & 100 & 14.4 & 100 & 3.6 & 100 & 51.2 & 100 \\
\hline
\end{tabular}

From the given data it is possible to see such. The geographical structure of migration of people of working age differs from the general structure: the first place is Donetsk region (21.3\%), while the second place is occupied by Kyiv (20.0\%), and the third center of gravity is Kharkiv region (13.3). \%). This distribution shows the attraction of able-bodied migrants to centers of economic activity, and indicative in this respect is the low level of migration of working-age IDPs to the government-controlled Luhansk region, as almost all major cities, ie centers of economic activity, remained in the occupied territory. In Ukraine as a whole, the share of people of working age in the structure of IDPs is $22.8 \%$, while this indicator varies greatly in the regional context.

Thus, in Donetsk and Luhansk oblasts the share of able-bodied persons in the total number of IDPs is only $13.5 \%$ and $11.0 \%$, respectively, and the closest lowest indicator of other regions is recorded in Khmelnytsky (26.7\%) and Zaporizhia (26.9\%) oblasts, which confirms the assumptions about «pension tourism» and the improbability of the real status of IDPs in Donetsk and Luhansk oblasts. Approximately the same situation can be observed for the group of IDPs represented by children, because in the structure of the number of IDPs who migrated to Donetsk and Luhansk regions, their share is the lowest in Ukraine, $13.8 \%$ and $7.9 \%$, respectively. At the same time, almost a third of this group is in the government-controlled territory of the Donetsk region, the second place is occupied by the city of Kyiv, and the third place is occupied by the government-controlled territory of the Luhansk region. In general, the majority of registered IDPs in Ukraine are people of retirement age (51.2\%); of these, the lion's share (79.2\%) falls on three regions, namely Donetsk, Luhansk and Kharkiv.

Thus, it can be argued that there are two relatively independent groups of officially registered IDPs that have specific characteristics: physical security; 2) persons of retirement age who actually live in the temporarily occupied territories, but are engaged in "shuttle" trips to receive pensions or to resolve legal and other cases in the territory controlled by the government.

The problems of the first group include: economic problems (the need to solve problems with housing in its absence or spend their own savings to buy housing in a new place of residence; low level of so-called resettlement payments, incompatible with the real needs for family expenses in a new place; finding a job or new business opportunities, a relatively lower level of income in a new place of residence, the existence of risks of losing property in the territory not controlled by the government); social problems (possible adverse treatment by the local community; problems of access to infrastructure (preschool and school education, medical care, sometimes - worse conditions of housing and communal, transport, recreational infrastructure, etc.), the need to adapt to new living conditions); administrative and legal problems (complexity and duration of receiving administrative services; uncertainty of the legal status of IDPs in the procedures of access to infrastructure, exercise of voting rights; discrimination in labor and property rights).

Among the problems of the second group of IDPs are: economic problems (the need to spend money on a "shuttle" trip at least once every 60 days for authentication, which, given the difference in pensions can be relatively expensive; relative increase in the cost of living with the desire to maintain its quality) ; social problems (possible unfavorable attitude of the local community and general over-humiliating attitude to "pension tourism"; problems of access to quality infrastructure, goods, medicines in places of permanent residence in the temporarily occupied territories, etc.; the need to adapt to new realities and statuses); administrative and legal problems (difficulty of crossing the line of demarcation between controlled and temporarily uncontrolled territory of Ukraine; difficulty of access and duration of receiving administrative services; uncertainty of legal status of IDPs in procedures of access to infrastructure, realization of voting rights; real or imaginary discrimination in pension rights; actions taken in Ukraine for the administrations of the so-called DPR and LPR, and vice versa).

However, despite difficult living conditions, employment problems and insufficient material security, $36 \%$ of IDPs do not plan to return to their homes before resettlement, even after the end of the conflict. Moreover, according to the ILO study, since March of this year, the share of those who do not plan to return has increased by $7 \%$. Instead, there are fewer people planning to do so after the conflict (from $32 \%$ to $22 \%$ ). These figures clearly show that over time, the mood of migrants will change. After all, five years is a long time.

People can't live on suitcases indefinitely, get a temporary job, wait indefinitely for a return. Every year the pain of loss recedes into the depths of the soul, wanderings harden, the realization comes that it is im- 
possible to enter the same river twice, and instead of hope for return other hopes come.

Conclusions. In general, the study allows us to formulate a number of features of IDP migration in Ukraine: 1) the number of IDPs has a declining trend, due to a number of reasons; 2) data on the number of IDPs cannot be accurate, as many IDPs do not did not receive this status officially; 3 ) the most important centers of gravity of migration flows are Donetsk and Luhansk regions; 4) the geographical structure of migration of people of working age differs from the general structure, because the Donetsk region remains in the first place, while the second place is occupied by the city of Kyiv, and the third center of gravity is the Kharkiv region; such a distribution illustrates the attraction of able-bodied migrants to the centers of economic activity; 5) distinguish two relatively independent groups of officially registered IDPs, the first of which are IDPs who are represented by persons of working age with families (children) who have actually left the territories temporarily out of control of the Ukrainian government in search of a better life and physical security; and the second, persons of retirement age who actually live in the temporarily occupied territories but are engaged in "shuttle" trips to obtain pensions or to resolve legal and other matters in the territory controlled by the government. It should be taken into account that in peacetime the problems of IDPs were solved by the state through the use of various socio-economic mechanisms. Other mechanisms should be involved in armed conflict, including the assistance of volunteer NGOs.

\section{Literature}

1. Украина стала четвертой в мире по числу беженцев. URL: http://cxid.info/ukraina-stala-chetvertoyv-mire-po-chislu-bejencev-n129196. 2. Слово і діло. Аналітичний портал. URL: https://www.slovoidilo.ua. 3. Обліковано 1413649 внутрішньо переміщених осіб. Міністерство соиіальної політики України. URL: https://www.msp.gov.ua/news/17733.html. 4. Внутрішньо переміщені особи на 10 червня 2019 р. Міністерство соиіальної політики України. URL: https: //www.msp.gov.ua/news/17193.html (дата звернення: 10.06.2019). 5. Про забезпечення прав і свобод внутрішньо переміщених осіб: Закон України від 20 жовтня 2014 р. № 1706-VII. Відомості Верховної Ради Украӥни. 2015. № 1. Ст. 1. 6. Про статус ветеранів війни, гарантії їх соціального захисту (із змінами) : Закон України від 5 лютого. 2015 р. № 157-VIII. Відомості Верховної Ради України. 1993. № 45. Ст. 425. 7. Питання забезпечення житлом внутрішньо переміщених осіб, які захищали незалежність, суверенітет та територіальну цілісність України : Постанова Кабінету Міністрів України від 18 квітня 2018 р. № 280. URL: https://zakon.rada.gov.ua/laws/show/ru/280-2018-\%D0\% BF. 8. Деякі питання забезпечення громадян доступним житлом : Постанова Кабінету Міністрів України від 10 жовтня 2018 р. № 819. URL: https://zakon.rada. gov.ua/laws/show/819-2018-\%D0\%BF. 9. Загальна інформація щодо місць компактного проживання (МКП) внутрішньо переміщених осіб станом на 1 січня 2019 р. Міністерство з питань тимчасово окупованих територій та внутрішньо переміщених осіб. URL: https: //mtot.gov.ua/ua/informacija-schodo-misc-kompaktnogoprojivannjamkp-vnutrishno-peremischenih-osib (дата звернення: 20.05.2019). 10. Новикова О. Ф. Трансформация проблем переселенцев Донбасса: от социальной защиты к ресурсу развития. Економічний вісник Донбасу. 2017. № 2 (48). С. 4-14. 11. Програма «доступне житло» для ВПО : звіт за результатами оцінювання УВКБ OOH. URL: https://www.unhcr.org/ua/wp-content/ uploads/sites/38/2019/02/2019-UNHCR-Evaluation-of-St ate-Youth-Fund-Housing-Programme-Final-Report.UKR _.pdf. 12. Регіональна програма будівництва, реконструкції, модернізації об’єктів інфраструктури, соціально-культурного та екологічного призначення по Запорізькій області на період до 2020 року. URL: http://zor.gov.ua/content/desyata-sesiyasomogo-sklykann ya-tretye-plenarnezasidannya.

\section{References}

1. Ukraina stala chetvertoy $\mathrm{v}$ mire po chislu bezhentsev [Ukraine became the fourth in the world in the number of refugees]. Retrieved from http://cxid.info/ ukraina-stala-chetvertoy-v-mire-po-chislu-bejencev-n129 196 [in Russian].

2. Word and deed. Analytical portal. Retrieved from https://www.slovoidilo.ua [in Ukrainian].

3. Oblikovano 1413649 vnutrishno peremishchenykh osib [1,413,649 internally displaced persons were registered]. Ministry of Social Policy of Ukraine. Retrieved from https://www.msp.gov.ua/news/17733.html [in Ukrainian].

4. Vnutrishno peremishcheni osoby na 10 chervnia 2019 r. [Internally displaced persons on June 10, 2019]. Ministry of Social Policy of Ukraine. Retrieved from https://www.msp.gov.ua /news/17193.html [in Ukrainian].

5. Pro zabezpechennia prav i svobod vnutrishno peremishchenykh osib: Zakon Ukrainy vid 20 zhovtnia 2014 r. № 1706-VII [On ensuring the rights and freedoms of internally displaced persons: Law of Ukraine of October 20, 2014 № 1706-VII]. (2015). Vidomosti Verkhovnoi Rady Ukrainy, 1, art. 1 [in Ukrainian].

6. SPro status veteraniv viiny, harantii yikh sotsialnoho zakhystu (iz zminamy) : Zakon Ukrainy vid 5 liutoho. 2015 r. № 157-VIII [On the status of war veterans, guarantees of their social protection (as amended): Law of Ukraine of 5 February. 2015 № 157-VIII]. (1993). Vidomosti Verkhovnoi Rady Ukrainy, 45, art. 425 [in Ukrainian].

7. Pytannia zabezpechennia zhytlom vnutrishno peremishchenykh osib, yaki zakhyshchaly nezalezhnist, suverenitet ta terytorialnu tsilisnist Ukrainy : Postanova Kabinetu Ministriv Ukrainy vid 18 kvitnia 2018 r. №280 [Issues of providing housing for internally displaced persons who defended the independence, sovereignty and territorial integrity of Ukraine: Resolution of the Cabinet of Ministers of Ukraine of April 18, 2018 № 280]. Retrieved from https://zakon.rada.gov.ua/laws/show/ru/280-2018-\% D0\%BF [in Ukrainian].

8. Deiaki pytannia zabezpechennia hromadian dostupnym zhytlom : Postanova Kabinetu Ministriv Ukrainy 
vid 10 zhovtnia 2018 r. № 819 [Some issues of providing citizens with affordable housing: Resolution of the Cabinet of Ministers of Ukraine of October 10, 2018 № 819]. Retrieved from https://zakon.rada.gov.ua/laws/show/8192018-\%D0\%BF [in Ukrainian].

9. Zahalna informatsiia shchodo mists kompaktnoho prozhyvannia (MKP) vnutrishno peremishchenykh osib stanom na 1 sichnia $2019 \mathrm{r}$. [General information on places of compact residence (ICP) for internally displaced persons as of January 1, 2019]. Ministry of the Temporarily Occupied Territories and Internally Displaced Persons. Retrieved from https://mtot.gov.ua/ua/informacija-schodomisc-kompaktnogo-projivannjamkp-vnutrishno-peremisc henih-osib [in Ukrainian].

10. Novykova, O. F. (2017). Transformation Problems of Immigrants from Donbass: from Social Welfare to Resource of Development. Ekonomichnyi visnyk Donbasu - Economic Herald of the Donbas, 2 (48), pp. 4 14 [in Russian].

11. Prohrama «dostupne zhytlo» dlia VPO : zvit za rezultatamy otsiniuvannia UVKB OON [Affordable Housing for IDPs: UNHCR evaluation report]. Retrieved from https://www.unhcr.org/ua/wp-content/uploads/sites/ 38/ 2019/ 02/ 2019 - UNHCR-Evaluation-of-State-YouthFund-Housing-Programme-Final-Report.UKR_.pdf [in Ukrainian].

12. Rehionalna prohrama budivnytstva, rekonstruktsii, modernizatsii obiektiv infrastruktury, sotsialnokulturnoho ta ekolohichnoho pryznachennia po Zaporizkii oblasti na period do 2020 roku [Regional program of construction, reconstruction, modernization of infrastructure, socio-cultural and environmental purposes in the Zaporozhye region for the period up to 2020]. Retrieved from http://zor.gov.ua/content/desyata-sesiyasomogo-sklykann ya -tretye-plenarnezasidannya[in Ukrainian].

Смирнова I. I., Чеботарьова В. О., Котелевець Ю. І., Курбацька Д. С. Стан вимушеної міграції та основні проблеми внутрішньо переміщених осіб в Україні

У статті розглянуто актуальні питання надання соціальної допомоги внутрішньо переміщеним особам. Визначено основні проблеми внутрішньо переміщених осіб. Відзначено, що оцінювання, збирання інформації та її аналіз, комплексна система спостережень ідентифікують стан вимушеного переселенця, що дає змогу виявити сутність правильного, ефективного, справедливого громадського розвитку. Проаналізовано стан нормативно-правового механізму вирішення житлової проблеми для вимушених переселенців на національному та регіональному рівнях. Запропоновано заходи щодо вдосконалення нормативно-правового механізму вирішення житлової проблеми вимушених переселенців.

Ключові слова: військовий конфлікт, внутрішньо переміщені особи, адаптація змушених переселенців, інституційні зміни, соціальне забезпечення, житлова проблема.

Smyrnova I., Chebotarova V., Kotelevets Yu., Kurbatska D. The State of Forced Migration and the Main Problems of Internally Displaced Persons in Ukraine

The article considers topical issues of providing social assistance to internally displaced persons. The main problems of internally displaced persons have been identified. It is noted that evaluation, collection of information and its analysis, a comprehensive system of observations identify the state of IDPs, which allows to identify the essence of proper, effective, equitable social development. The state of the normative-legal mechanism of solving the housing problem for IDPs at the national and regional levels is analyzed. Measures to improve the regulatory and legal mechanism for solving the housing problem of internally displaced persons are proposed.

Keywords: military conflict, internally displaced persons, adaptation of IDPs, institutional changes, social security, housing problem.

Смирнова И. И., Чеботарёва В. А., Котелевец Ю. И., Курбацкая Д. С. Состояние вынужденной миграции и основные проблемы внутренне перемещенных лиц в Украине

В статье рассмотрены актуальные вопросы предоставления социальной помощи внутренне перемещенным лицам. Определены основные проблемы внутренне перемещенных лиц. Отмечено, что оценивание, сбор информации и ее анализ, комплексная система наблюдений идентифицируют состояние вынужденного переселенца, который дает возможность проявить сущность правильного, эффективного, справедливого общественного развития. Проанализировано состояние нормативно-правового механизма решения жилищной проблемы для вынужденных переселенцев на национальном и региональном уровнях. Предложены мероприятия по усовершенствованию нормативноправового механизма решения жилищной проблемы вынужденных переселенцев.

Ключевые слова: военный конфликт, внутренне перемещенные лица, адаптация вынужденных переселенцев, институционные изменения, социальное обеспечение, жилищная проблема.

Received by the editors: 12.10 .2020 and final form 29.12.2020 